Program Studi Magister Pendidikan Fisika UNP, Padang 11 November 2017

This page left intentionally blank 


\title{
Upaya Peningkatan Kemampuan Guru IPA SMP dan MTs dalam Merancang Karya Inovatif untuk Menunjang Kegiatan Pembelajaran
}

\author{
Rio Anshari ${ }^{(1)^{*}}, \operatorname{Akmam}^{(1)}, \operatorname{Hidayati}^{(1)}$, dan Renol Afrizon ${ }^{(1)}$ \\ (1) Jurusan Fisika, FMIPA, Universitas Negeri Padang, Padang \\ *e-Mail : rioanshari@fmipa.unp.ac.id
}

\begin{abstract}
ABSTRAK
Tenaga pendidik yang selanjutnya disebut guru, pada hakikatnya dituntut untuk memiliki kompetensi yang meliputi empat kompetensi, yaitu kompetensi pedagogik, kompetensi profesional, kompetensi kepribadian dan kompetensi sosial. Pada kompetensi professional, guru diharuskan menguasai bidang yang diasuhnya dan dapat melakukan perbaikan terus menerus sebagai bentuk usaha peningkatan kompetensinya. Salah satu usahanya adalah dengan melakukan kegiatan penelitian dan menghasilkan karya-karya inovatif. Pemerintah sendiri juga memfasilitasi dan memotivasi guru untuk secara konsisten dan berkala mengembangkan kompetensi ini, salah satunya adalah mengharuskan guru menghasilkan karya ilmiah sebagai persyaratan pada kegiatan kompetisi guru seperti kegiatan guru berprestasi, guru teladan dan sebagainya. Selain itu, untuk kenaikan pangkat tertentu sekarang juga diharus bagi guru-guru menghasilkan karya ilmiah maupun membuat PTK di kelas yang diajarnya yang tak lain adalah untuk menghasilkan SDM guru yang bagus. Menjawab tentangan itu, UNP sebagai salah satu LPTK penghasil guru, khususnya di Provinsi Sumatera Barat merasa perlu memberikan pembekalan bagi guru-guru di lapangan agar dapat bersinergi dan merespon tentangan ini dengan baik dan efisien.

Analisis data awal dari subjek yang diteliti yaitu Guru IPA SMP dan MTs Kabupaten Agam memperlihatkan $44 \%$ dari objek yang diamati masih belum memiliki persiapan untuk dapat menghasilkan karya inovatif. Bentuk ketidaksiapan ini diantaranya meliputi pengetahuan yang kurang mengenai karya inovatif (59\%), kurangnya pengalaman dalam menghasilkan sebuah karya inovatif (23\%), kurangnya daya tanggap (respon) subjek serta kurangnya pelatihan yang diperoleh subjek dari tenaga ahli (82\%).

Setelah diberikan pembekalan, pendampingan dan pembinaan terhadap subjek yang diteliti, terlihat perubahan yang cukup signifikan. Sebanyak $76 \%$ dari subjek yang diteliti telah dapat memahami tentang karya inovatif, $82 \%$ dari subjek yang diteliti terbantu untuk menghasilkan karya inovatif. Mulai terbentuk respon positif dari subjek, $82 \%$ dari subjek menilai kreativitasnya mulai terbentuk, $79 \%$ subjek merasa lebih percaya diri dalam menghasilkan karya inovatif serta munculnya kerjasama antara sesama subjek yang diteliti.
\end{abstract}

KATA KUNCI: Karya Inovatif, Penelitian Tindakan Kelas, Media Pembelajaran Interaktif 


\section{PENDAHULUAN}

Kemajuan dan perkembangan suatu bangsa, baik secara langsung ataupun tidak langsung bergantung pada kualitas pendidikannya. Banyak faktor yang mempengaruhi kualitas pendidikan yang diselenggarakan oleh suatu bangsa. Hasbullah (Hasbullah, 2009) mengungkapkan setidaknya terdapat 7 faktor yang mempengaruhi kualitas pendidikan di Indonesia yaitu diantaranya : 1) Rendahnya Kualitas Sarana Fisik; 2) Rendahnya Kualitas Guru; 3) Rendahnya Kesejahteraan Guru; 4) Rendahnya Prestasi Siswa; 5) Kurangnya Pemerataan Kesempatan Pendidikan; 6) Rendahnya Relevansi Pendidikan dengan Kebutuhan; dan 7) Mahalnya Biaya Pendidikan. Ketujuh faktor tersebut saling mempengaruhi satu dengan yang lainnya dalam menentukan kualitas pendidikan yang dihasilkan.

Dari aspek yang mempengaruhi kualitas pendidikan di Indonesia yang dipaparkan sebelumnya, yang menjadi fokus perhatian dan akan diformulasikan solusinya adalah rendahnya kualitas guru. Berbagai cara telah ditempuh pemerintah untuk terus memperbaiki kualitas guru dari tahun ke tahun seperti memberikan pelatihan, diklat, workshop dan lain sebagainya. Adanya Ujian Kompetensi Guru (UKG) dan adanya program Guru Pembelajar merupakan salah satu dari sekian banyak usaha pemerintah untuk secara berkesinambungan terus meningkatkan kompetensi guru. Selain itu juga pemerintah secara terus menerus merangsang guru-guru untuk terus mengembangkan kompetensinya dengan mangadakan kegiatan perlombaan dan kompetisi yang bersifat kompetitif seperti Lomba guru berprestasi, Olimpiade Guru Nasional (OGN), lomba guru teladan dan masih banyak kegiatan sejenis lainnya.

Selain dari upaya yang dijabarkan di atas, pemerintah melalui pemberlakuan Peraturan Menteri Negara Pendayagunaan Aparatur Negara dan Reformasi Birokrasi (Permenneg PAN dan RB) Nomor 16 Tahun 2009 sebagai penyempurnaan Keputusan Menteri Negara Pendayagunaan Aparatur Negara (Kepmenneg PAN) Nomor 84 Tahun 1993 tentang Jabatan Fungsional Guru dan Angka Kreditnya, maka guru mendapatkan kesempatan lebih besar agar lebih profesional. Tuntutan guru mewujudkannya melalui kegiatan pengembangan profesi yang sekarang disebut sebagai Pengembangan Keprofesian Berkelanjutan (PKB). Pengembangan Keprofesian Berkelanjutan (PKB) adalah pengembangan kompetensi guru yang dilaksanakan sesuai dengan kebutuhan, bertahap, berkelanjutan untuk meningkatkan profesionalitasnya (KemenPanRB, 2009).

PKB memberikan kesempatan yang sebesarbesarnya bagi guru untuk dapat memberikan sumbangsih lebih untuk memajukan pendidikan di Indonesia. PKB sendiri memiliki tiga program utama yang sifatnya berkelanjutan, yaitu diantaranya 1) pengembangan diri; 2) publikasi ilmiah; dan 3) karya inovatif. PKB ini memberikan tantangan baru bagi guru dan memberikan motivasi lebih bagi guru untuk terus menerus secara berkesinambungan mengembangkan kompetensinya. Namun, tantangan itu sendiri disikapi oleh guru dengan dua reaksi. Bagi guru yang merasa dengan adanya tantangan maka akan memaksa mereka untuk berubah menyesuaikan sehingga pada akhirnya dapat mengikuti tuntutan tantangan tersebut. Namun demikian, sebagian guru lainnya mendapat tekanan dan stress dengan adanya tantangan ini yang berakibat terus menurunnya motivasi kerja dan prestasinya. Diantara tiga program yang dinaungi PKB ini, publikasi ilmiah dan karya inovatif sangatlah menjadi permasalahan di kalangan guru karena sebagian besar guru mengalami kesulitan untuk memenuhi tuntutan program tersebut.

Menyikapi kondisi di atas, perlu kiranya dilakukan upaya untuk meningkatkan kemampuan guru dalam merancang, melaksanakan dan mengevaluasi karya inovatif. Pada kegiatan yang telah dilakukan, focus aspek yang diteliti masih dibatasi pada tahap kemampuan merancang karya inovatif.

cnsi-kompetensi khusus yang menunjang peranannya dalam mendidik dan mengajar siswa. Kompetensi sendiri pada hakikatnya adalah seperangkat pengetahuan, keterampilan dan perilaku yang harus dimiliki, dihayati dan dikuasai oleh guru atau dosen dalam melaksanakan tugas keprofesionalannya. Guru diharuskan menguasai empat kompetensi yaitu meliputi 1) kompetensi pedagogik; 2) kompetensi profesional; 3) kompetensi kepribadian; dan 4) kompetensi sosial (Depdiknas, 2005). Keempat kompetensi tersebut seharusnya sudah dimiliki oleh seorang guru yang berkualitas. Keempat kompetensi tersebut tidak berdiri sendiri, melainkan saling berhubungan dan saling mempengaruhi serta saling menjadi dasar satu sama lainnya. Gambar 1 berikut memperlihatkan keempat kompetensi yang harus dimiliki oleh seorang Guru yang profesional. 


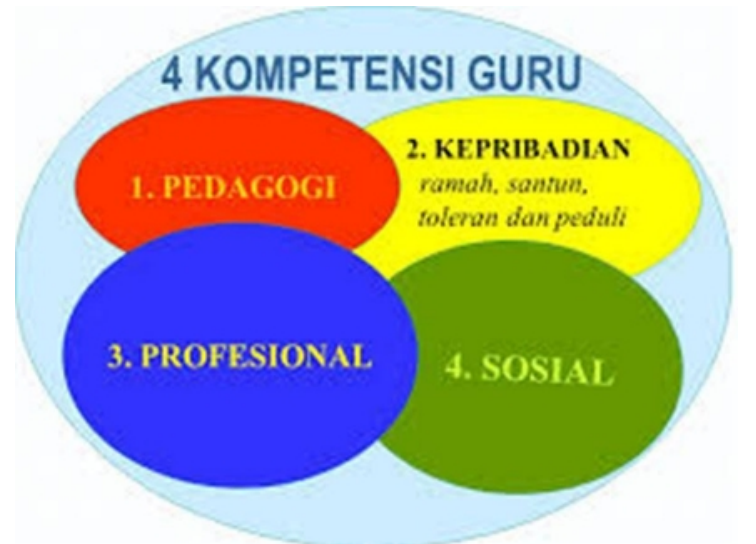

Gambar 1. Empat jenis kompetensi guru.

\section{PENGEMBANGAN KEPROFESIAN BERKELAN- JUTAN (PKB)}

PKB guru terdiri atas 3 (tiga) kelompok kegiatan, yaitu pengembangan diri, publikasi ilmiah, dan karya inovatif. Gambar 2 memperlihatkan hubungan ketiganya. Kegiatan pengembangan diri bertujuan untuk meningkatkan kompetensi guru. Kegiatan publikasi ilmiah untuk memenuhi kegiatan memperbaiki proses pembelajaran, dan kegiatan karya inovatif bertujuan untuk menerapkan kompetensi sehubungan dengan penggunaan media dan atau alat dalam pembelajaran. Porsi ketiga kegiatan bervariasi pada masing-masing jenjang kepangkatan guru. Bentuk-bentuk kegiatan dari ketiga kelompok kegiatan tersebut dapat dilihat pada gambar 3. Dengan adanya PKB ini, harapan para pengambil kebijakan adalah guru dapat mulai mengembangkan profesi dari guru golongan III/a. Jika guru telah dibiasakan melakukan sejak dini, maka guru profesional lebih mudah diwujudkan. Kegiatan PKB meningkat sesuai dengan jenjang kepangkatan. Semakin tinggi jenjang kepangkatan guru, maka semakin besar pula tuntutan kepada guru tersebut mengikuti kegiatan pengembangan diri. Selain itu, untuk kegiatan publikasi ilmiah dan karya inovatif, tuntutan melakukannya yang meliputi macam dan lingkup juga semakin tinggi.

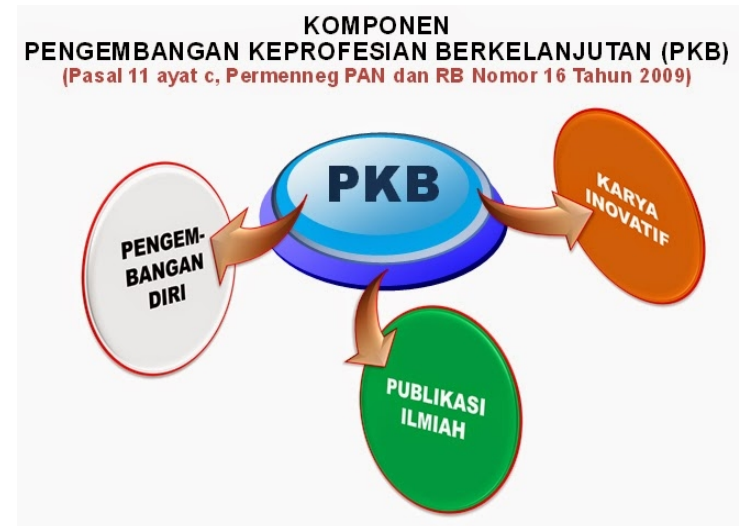

Gambar 2. Komponen PKB

Guru profesional adalah sebuah keniscayaan untuk diwujudkan. Guru adalah pendidik profesional dengan tugas utama mendidik, mengajar, membimbing, mengarahkan, melatih, menilai, dan mengevaluasi peserta didik pada pendidikan anak usia dini jalur pendidikan formal, pendidikan dasar, dan pendidikan menengah (Depdiknas, 2005). Agar berhasil melakukan tugas-tugas tersebut, diharapkan guru memiliki modal kemampuan agar dapat mewujudkannya.

Kegiatan PKB berdasarkan Permenneg PAN \& RB Nomor 16 Tahun 2009 tentang Jabatan Fungsional Guru dan Angka Kreditnya, merupakan salah satu unsur utama yang diberikan angka kredit untuk kenaikan pangkat/jabatan fungsional guru. Guru yang profesional adalah guru yang dapat menunjukkan pencapaian angka kredit yang memenuhi untuk setiap jenjangnya. Dengan demikian kedudukan guru profesional ekivalen dengan pencapaian pangkat yang diperolehnya.

Karya inovatif ini mencakup a)Penemuan teknologi tepat guna kategori kompleks dan / atau sederhana; b) Penemuan / peciptaan atau pengembangan karya seni kategori kompleks dan / atau sederhana; c) Pembuatan / pemodifikasian alat pelajaran / peraga / praktikum kategori kompleks dan/ atau sederhana; dan d) Penyusunan standar, pedoman, soal dan sejenisnya pada tingkat nasional maupun provinsi.

Fokus karya inovatif yang dikembangkan pada subjek yang diteliti adalah penemuan teknologi tepat guna kategori kompleks dan / atau sederhana yang kemudian dengan skop yang lebih kecil lagi yaitu karya inovatif berupa menghasilkan Penelitian Tindakan Kelas (PTK) yang berkualitas serta menghasilkan media pembelajaran yang interaktif. 


\section{KONDISI AWAL OBJEK PENELITIAN TERKAIT KESIAPANNYA DALAM MENGHADAPI PKB}

\section{METODE}

Metode penelitian yang digunakan dalam penelitian ini yaitu metode deskriptif. Metode deskriptif menurut Hasbullah (2009 : 6) adalah "metode yang lebih mengarah pada pengungkapan suatu masalah atau keadaan sebagaimana adanya dan mengungkap fakta-fakta yang ada, walaupun kadangkadang diberikan interprestasi dan analisis", sedangkan jika mengacu pada pelaksanaannya, metode penelitian yang digunakan adalah metode survey. Menurut Hasbullah (2009: 9) survey adalah "suatu metode penelitian yang bertujuan untuk mengumpulkan sejumlah besar data berupa variabel, unit atau individu dalam waktu yang bersamaan". Metode survey yang dilakukan dalam penelitian ini bertujuan untuk mengumpulkan data yang dibutuhkan untuk mendukung analisis data.

Instrumen penelitian yang digunakan yaitu dengan menggunakan angket / kuisioner. Angket yang digunakan berupa angket tertutup dengan pilihan untuk memperoleh kondisi dari objek yang diamati dan angket terbuka untuk mendapatkan umpan balik dari objek yang diteliti.

\section{HASIL}

Perlakuan (treatment) yang diberikan yaitu berupa pelatihan dan pembimbingan bagi guru-guru dalam merancang karya inovatif, khususnya dalam membuat rancangan proposal Penelitian Tindakan Kelas dan membuat rancangan Media Pembelajaran Interaktif. Beberapa aspek yang menjadi fokus perhatian dalam pengambilan data penelitian secara general dapat dikelompokkan menjadi dua kelompok, yaitu kondisi awal objek penelitian terkait kesiapannya dalam menghadapi PKB; dan kondisi objek dalam seteleh memperoleh treatment.
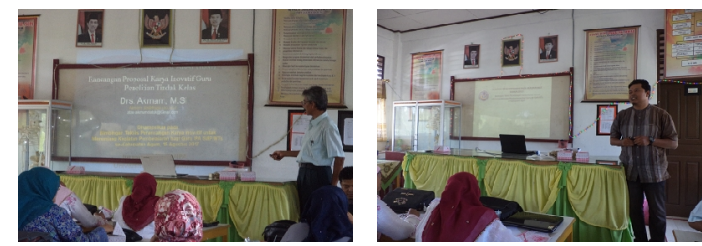

Gambar 3. Pelaksanaan pelatihan dan pembimbingan.
Kondisi awal objek penelitian terkait kesiapannya dalam menghadapi PKB diamati dari beberapa aspek yaitu diantaranya :

1) Pengetahuan awal guru tentang Karya Inovatif.

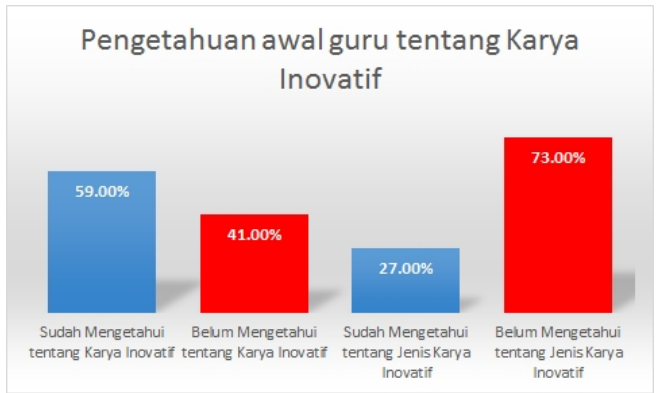

Gambar 4. Pengetahuan awal guru tentang Karya Inovatif

2) Pengetahuan awal guru tentang Penelitian Tindakan Kelas.

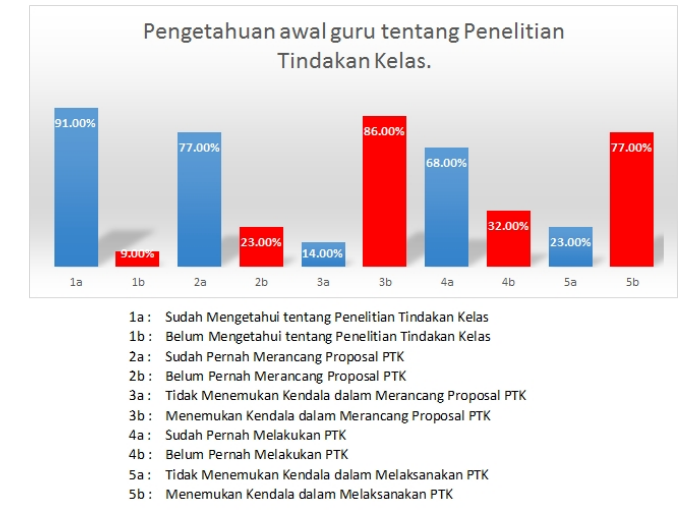

Gambar 5. Pengetahuan awal guru tentang Penelitian Tindakan Kelas.

3) Pengetahuan awal guru tentang Media Pembelajaran Interaktif. 


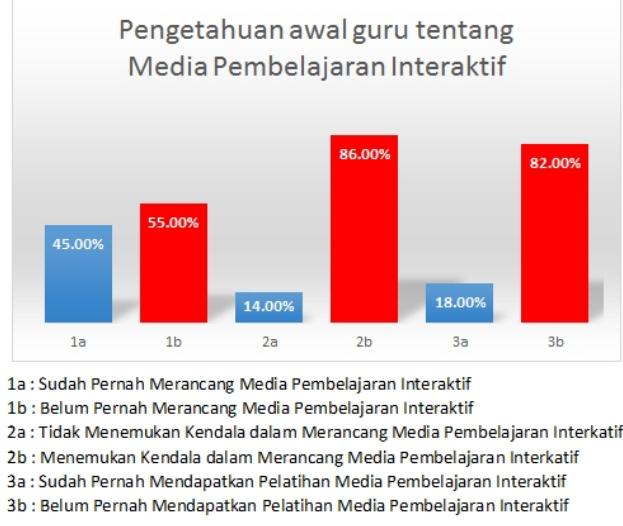

Gambar 6. Pengetahuan awal guru tentang Media Pembelajaran Interaktif.

\section{KONDISI OBJEK PENELITIAN SETELAH DIBERIKAN TREATMENT}

Adapun perubahan yang diamati dari objek yang diamati yaitu guru setelah diberikan treatment berupa pelatihan dan pembimbingan dalam merancang karya ilmiah dapat diamati sebagai berikut :

1) Pengetahuan Guru tentang Karya Inovatif

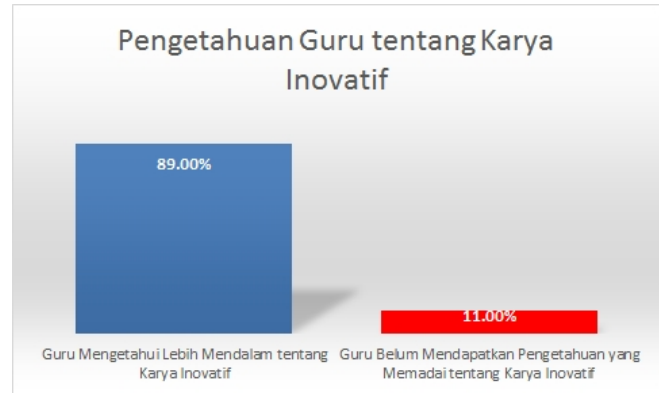

Gambar 7. Pengetahuan Guru tentang Karya Inovatif

2) Pengetahuan Guru tentang Penelitian Tindakan Kelas.

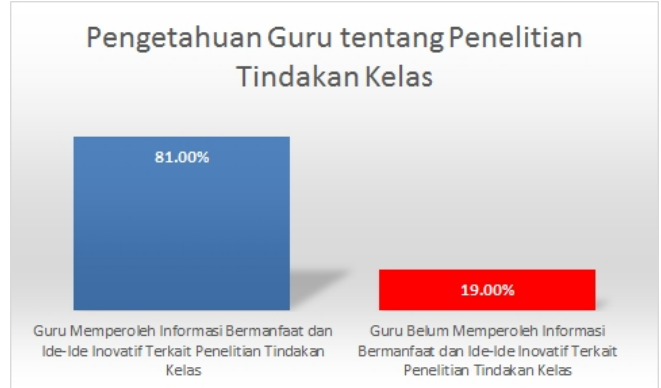

Gambar 8. Pengetahuan Guru tentang Penelitian Tindakan Kelas.
3) Pengetahuan Guru tentang Media Pembelajaran Interaktif.

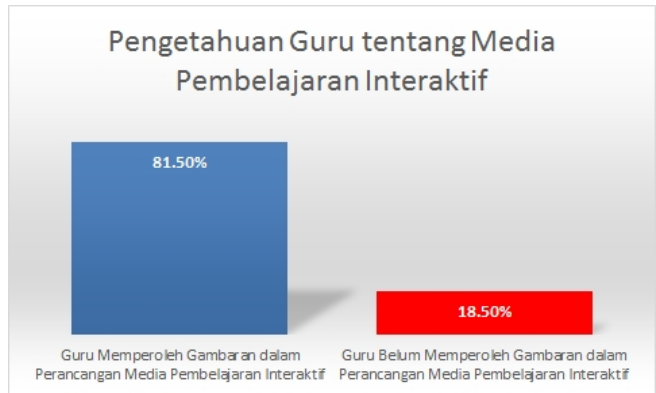

Gambar 9. Pengetahuan Guru tentang Media Pembelajaran Interaktif.

4) Hasil Tambahan

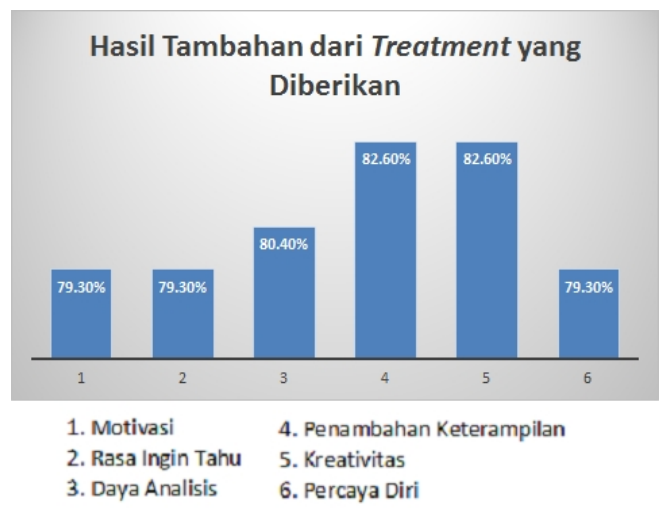

Gambar 10. Hasil tambahan yang diperoleh dari treatment yang diberikan.

\section{PEMBAHASAN}

Peneliti memperhatikan beberapa aspek kondisi awal objek yang diamati terkait dengan kesiapannya dalam menghadapi PKB, terutama dalam merancang dan menghasilkan karya inovatif memperlihatkan sebagian besar guru belum memiliki persiapan yang matang untuk menghadapi PKB. Kumulatif kondisi objek yang diteliti terkait persiapannya dalam menghadapi PKB didapat dari menganalisis dan mentabulasi data yang diperoleh dari hasil pelaksanaan perlakuan/treatment sesuai dengan yang terlihat pada grafik berikut. 


\section{PPOSIDING SEHINAR NASIONAL PEMBELLAJRAA FISIKA IV}

Program Studi Magister Pendidikan Fisika UNP, Padang 11 November 2017

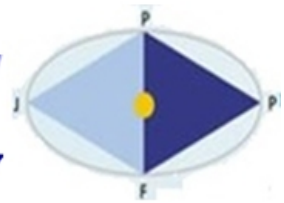

Kesiapan Guru untuk Menghadapi PKB dari Aspek Kemampuan Guru dalam Merancang dan Menghasilkan Karya Inovatif
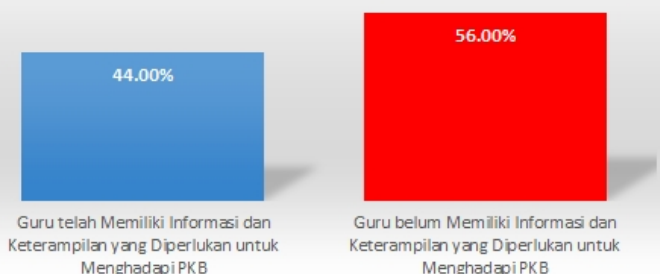

Gambar 11. Kesiapan Guru untuk Menghadapi PKB.

Beberapa fakta yang ditemukan yang memperlihatkan masih banyak dari guru yang belum memiliki kesiapan antara lain sebagai berikut :

1) Dalam merancang karya inovatif, yaitu dalam hal ini karya inovatifnya berupa PTK dan Media Pembelajaran Interaktif, guru masih banyak yang belum mengikuti langkah-langkah / prosedur yang sesuai.

2) Guru masih enggan untuk melakukan penelitian ataupun mengembangkan Media Pembelajaran.

3) Guru belum mampu mengintegrasikan PTK yang telah / akan dilaksanakannya di kelas yang guru tersebut ajar.

4) Guru masih belum memahami konsep "Media Pembelajaran Interaktif" yang benar karena Media Pembelajaran yang selama ini telah dikembangkan sangat minim unsur "Interaktifitas", bahkan cenderung bersifat satu arah.

5) Sebesar $82 \%$ dari objek yang diamati mengungkapkan kalau mereka belum memperoleh pelatihan yang cukup untuk dapat meningkatkan pengetahuan dan keterampilannya.

Setelah diberikan perlakuan (treatment) yaitu pelatihan dan pembimbingan dalam merancang karya inovatif, sebagian besar sasaran penelitian menyampaikan adanya perubahan dari bagaimana cara mereka memandang dan melaksanakan Penelitian Tindakan Kelas dan Pengembangan Media Pembelajaran Interaktif. Dari produk rancangan yang dihasilkan oleh objek yang diteliti sudah pada kategori layak untuk dilaksanakan ataupun dikembangkan.

\section{KESIMPULAN}

Penelitian tentang upaya peningkatan kemampuan guru dalam merancang karya inovatif telah dilaksanakan dan diperoleh hasil sebagai berikut :

1) Sebagian besar guru yang diamati dalam kegiatan belum memiliki kesiapan dalam menghadapai $\mathrm{PKB}$, terutama dalam menghasilkan sebuah karya inovatif.

2) Ketidaksiapan dari guru-guru tersebut beberapanya disebabkan oleh kurangnya pengetahuan guru tentang karya inovatif, kurangnya motivasi dan rasa ingin tahu, serta kurangnya keterampilan yang diperlukan untuk menghasilkan karya inovatif.

3) Perlunya diberikan pelatihan dan pembimbingan secara berkala dan berkelanjutan untuk dapat meningkatkan kemampuan guru-guru yang diteliti dalam merancang karya inovatif.

\section{UCAPAN TERIMAKASIH}

Penelitian ini dibiayai dari pendanaan PNBP UNP tahun anggaran 2017. Ucapan terimakasih peneliti ucapkan kepada Universitas Negeri Padang, yaitu kepada Lembaga Penelitian dan Pengabdian Masyarakat (LP2M) atas support yang telah diberikan.

\section{DAFTAR PUSTAKA}

Depdiknas. (2005). Undang - Undang RI Nomor 14 Tahun 2005 Tentang Guru dan Dosen. Jakarta: Pemerintah RI.

Hasbullah. (2009). Dasar - dasar Ilmu Pendidikan. Jakarta: PT. Raja Grafindo Persada.

Kemdikbud. (2012). Buku 1 Pedoman Pengelolaan Pengembangan Keprofesian Berkelanjutan. Jakarta: Pemerintah RI.

KemenPanRB. (2009). Peraturan Menteri Negara Pendayagunaan Aparatur Negara dan Reformasi Birokrasi Nomor 16 Tahun 2009 tentang Jabatan Fungsional Guru dan Angka Kreditnya. Jakarta: Pemerintah RI.

Slameto. (2003). Belajar dan Faktor - faktor Yang Mempengaruhinya. Jakarta: PT. Rineka Cipta. 
Program Studi Magister Pendidikan Fisika UNP, Padang 11 November 2017

This page left intentionally blank 